\title{
Residues and dissipation of imidacloprid in pomegranate fruits
}

\author{
D.R. KADAM*1, B.V. DEORE ${ }^{2}$ AND S.M. UMATE ${ }^{1}$
}

${ }^{1}$ Department of Entomology, Mahatama Phule Krishi Vidyapeeth, Rahuri, AHMEDNAGAR (M.S.) INDIA ${ }^{2}$ Department of Agriculture Entomology, Vasantrao Naik Marathwada Phule Krishi Vidyapeeth, PARBHANI (M.S.) INDIA

Field and laboratory studies on residues and dissipation of imidacloprid in pomegranate fruits were conducted during 2010 at the Pesticide Residue analysis laboratory, Department of Entomology, Mahatma Phule Krishi Vidyapeeth, Rahuri, Ahmednagar, M.S. (India). The studies revealed that residues of imidacloprid persisted up to 3 days and 5 days in arils, 5 days and 7 days in whole fruits and 7 days and 10 days in peel of pomegranate fruits at recommended and higher doses, respectively.

Key words : Pomegranate, Imidacloprid, Residues

How to cite this paper : Kadam, D.R., Deore, B.V. and Umate, S.M. (2014). Residues and dissipation of imidacloprid in pomegranate fruits. Asian J. Bio. Sci., 9 (2) : 246250. 